Article

\title{
In the Bullseye of Vigilantes: Mediated Vulnerabilities of Kyrgyz Labour Migrants in Russia
}

\author{
Rashid Gabdulhakov \\ Department of Media and Communication, Erasmus University, 3000 DR Rotterdam, The Netherlands; \\ E-Mail: gabdulhakov@eshcc.eur.nl
}

Submitted: 15 December 2018 | Accepted: 12 April 2019 | Published: 28 June 2019

\begin{abstract}
Hundreds of thousands of Kyrgyz labour migrants seek opportunities in Russia where they fall target to retaliation of vigilante citizens who find offence in the presence of alien labourers in their homeland. Vigilantism also takes place within this migrant 'community' where male Kyrgyz labour migrants engage in retaliation on female migrants over perceived offences such as dating non-Kyrgyz men. On several occasions between 2011 and 2016 videos featuring honour beating of female labour migrants by fellow countrymen shook the internet. The selected case illustrates vulnerabilities experienced by migrants due to xenophobia and hostility of the host state, as well as additional layers of vulnerabilities linked to gendered biases that 'travel' across borders along with compatriots in migration. The study argues that offline structures, norms, biases, violence, and stigma not only reincarnate online, where they culminate in vigilante acts, but consequently, they re-enter the offline discourse and go through further normalization and justification.
\end{abstract}

\section{Keywords}

digital divides; digital vigilantism; layers of vulnerabilities; labour migrants

\section{Issue}

This article is part of the issue "Refugee Crises Disclosed: Intersections between Media, Communication and Forced Migration Processes", edited by Vasiliki Tsagkroni (Leiden University, The Netherlands) and Amanda Alencar (Erasmus University Rotterdam, The Netherlands).

(C) 2019 by the author; licensee Cogitatio (Lisbon, Portugal). This article is licensed under a Creative Commons Attribution 4.0 International License (CC BY).

It is ugly to be punishable, but there is no glory in punishing. (Foucault, 1977, p. 10)

\section{Introduction}

Social media and smart mobile devices brought about intrinsic changes to various aspects of modern life, including the process and experience of migration. Digital media attests its unprecedented affordances for migrants, such as access to crucial information, on-the-spot translation, navigation tools, and other services conveniently accessible through a single device. As is evident from recent literature on the role of digital media in the lives of refugees, displaced people, and migrants - smart mobile devices, social media, and connectivity that they afford can be positively instrumental during and after the migratory journey. From coordination with others in the com- munity, to maintaining contact with people back home, to document storing-smartphones provide a "sense of security" and help with "preserving memories" of the journey (Alencar, Kondova, \& Ribbens, 2018, pp. 12-13). Social media is used by refugees for "acquisition of language and cultural competences" and helps with "contacting family and friends in the home country in order to obtain social and emotional support" (Alencar, 2017 , p. 1600). At the same time, there are certain "information precarities" experienced by refugees and displaced people; such precarities constitute instabilities and vulnerabilities to "misinformation, stereotyping, and rumors" (Wall, Otis Campbell, \& Janbek, 2017, p. 240). This article aims to make a scientific contribution by addressing mediated vulnerabilities of Kyrgyz labour migrants in Russia who are pushed out of their home state by economic factors, and whose precarious status in the 
host state amplifies their fragility in the digital domain. In particular, the article inquires into how digital vigilantism affects female labour migrants in the framework of the digital divides (Miller \& Norris, 2016; Ragnedda \& Ruiu, 2017; van Dijk, 2017; among others) that imply divergence across groups and individuals in their access to digital media, respective skills, as well as various capitals and benefits of using these media. By addressing the selected case, this article aims to further inform the scientific discussion, debate, and exchange on the role, benefits, and harms that digital media can bring into the lives of migrants. The study considers how the established social, political, and economic inequalities, as well as racial, ethnic, and other biases transfer into the digital sphere, thus reinforcing the "existing social relationships" (van Dijk, 2012, p. 243), where they "culminate in a coordinated mass persecution of a targeted citizen" (Trottier, 2017, p. 61), and then re-enter the offline sphere and discourse.

Falling target to vigilante citizens in the host state, labour migrants from Kyrgyzstan engage in mediated moral policing within their own perceived community. On several occasions between 2011 and 2016 videos featuring honour beating of female Kyrgyz labour migrants by fellow countrymen shook the internet. Referring to themselves as 'patriots', men, who do not reveal own identity in the videos, humiliate and punish women over perceived offences, such as being seen in public with non-Kyrgyz males. Having found offence in women's behaviour, the 'patriots' capture and beat their targets, threaten them with knives, sexually assault them, film the process, and spread the footage online (Beishinbek Kyzy \& Bigg, 2012; Botoeva, 2012; SOVA Center for Information and Analysis, 2012; Ibraeva, Moldosheva, \& Ablezova, 2015; Lelik, 2016). Beyond the suffered embodied harms, visibility of the targets is exploited (Trottier, 2017) as they are forced to reveal their names and home addresses on camera, which intensifies harms and sets paths for further online and offline retaliation, shaming, and harassment.

Certain identity markers such as nationality, ethnicity, religion, sexual orientation, and gender, as well as social norms, and perceived obligations, affect the subjection to and experience of digitally mediated citizenled retaliation. The selected case illustrates vulnerabilities that migrants experience due to xenophobia and hostility in the host state, as well as gendered biases and violence inside of the migrant 'community'. Such vulnerabilities are, of course, numerous and extend across economic factors, education, healthcare, employment conditions, immigration status, and so on. This article focuses on vulnerabilities associated with subjection to vigilante acts that instrumentalise embodied and digitally mediated retaliation.

After elaboration on its methodology, the article provides a theoretical framework for digital vigilantism and digital divides. In doing so, it covers respective literature and the encompassing scholarly discussions. The article proceeds to elaborate on various threats and vulnerabilities faced by Kyrgyz labour migrants in Russia amid the multitude of 'offences' that certain targets emit. Women are targeted by vigilantes in the host-state and by compatriots in migration. In this case, there are vulnerabilities applicable to the general group 'Kyrgyz labour migrants in Russia', as well as additional vulnerabilities experienced by women within the group. Beyond this, women experience barriers to seeking legal help, as sexual violence, shame, weak rule of law, and uncertain legal status in Russia prevent them from being vocal. Appalling public solidarity with vigilante acts in the home state of Kyrgyzstan is informed by stigma, victim-blaming discourses, and vulnerable positions of women within the set social norms.

\section{Methodology}

Being part of the larger international and interdisciplinary project that investigates the manifestation of digital vigilantism across various political and social contexts, the study relies on a mixed methodology. Though scarce, the existing literature on the selected case assisted in constructing an understanding of perceptions and public reactions to instances of digitally mediated vigilante retaliation. Semi-structured in-depth interviews with vigilantes (1), human rights defenders (3), police (2), academics (1), NGO representatives (1), and journalists (3), conducted in Russia and Kyrgyzstan in person and via Skype, have further informed this research. Interviews were conducted between April and June 2018. The option of interviewing targets of digital vigilantism was intentionally avoided due to ethical considerations and do no harm approach of the researcher. All featured interviewees in the study are anonymised, which has no impact on the substance and quality of the data. Interview material particularly helped with the contextualisation of digitally mediated retaliation and its impacts on targets within the Kyrgyz migrant 'community'. Interviews revealed instances of collaboration between law enforcement officers and vigilante citizens in Russia, disclosing curious nuances of acquired capitals and powers that allow media-savvy participants to apply pressure on the police. Furthermore, the informants helped shed light on the barriers that prevent targets from seeking legal help both in the host state and in their home country.

\section{Digital Vigilantism}

Finding offence in other citizens, taking personal retaliation measures while filming the process and subsequently disseminating the footage online is a rampant practice among various vigilante groups in Russia. In the majority of cases, participatory practices are group acts where citizens organise themselves around a selected offence theme, such as exposing and punishing alleged paedophiles, countering 'unscrupulous' merchants, shaming parking 'violators', or busting 'illegal mi- 
grants'. This article relies on the concept of digital vigilantism to address such acts. Researching vigilantism through the prism of its digital manifestations should not be perceived as a phenomenon limited to hacking and doxing. Instead, digital vigilantism can be defined as "a process where citizens are collectively offended by other citizen activity, and coordinate retaliation on mobile devices and social platforms" (Trottier, 2017, p. 56). As such, embodied acts performed by vigilantes and broadcasted online are also regarded as acts of digital vigilantism. The element of digitally mediated exposure of targets can bring about longevity and recurrence of the waves of harms that a sole physical assault would not be able to enact, thus intensifying and amplifying the impact of retaliation. Russia's neo-Nazi vigilante group Occupy Paedophilia, for instance, engaged in intentional dissemination of the footage of their punitive acts "in order to extend the sexual humiliation and punishment beyond the actual physical assault behind closed doors" (Kasra, 2017, p. 185). While such "unwanted', "intense", and "enduring" (Trottier, 2017, p. 56) visibility is forced on the targets, publicity can be the desired opportunity for vigilantes, granting them social recognition as informal justice providers; although participants too can experience negative consequences of own visibility.

Moncada (2017) proposes five core definitional dimensions of vigilantism, namely, social organisation, targets, repertoire, justification, and motivation (pp. 407-408). Here it is important to consider respective biases that might subject certain categories of people to being vulnerable to retaliation in specific contexts; i.e., ethnic/religious/sexual minorities, representatives of a certain socio-economic class, women, migrants, etc. As digital media brought about "dramatic increases in harassment, abuse, and threats targeting women" (Jane, 2017, p. 186), the very biology as an identity marker can lead to vulnerability. When it comes to citizen response to perceived offences, questions of motivation, legality, and proportionality of retaliation arise. These questions are, of course, also applicable to the authorised state forces such as the police and the Federal Migration Service. Unlike conventional vigilantes, who, according to Johnston (1996), constitute autonomous citizenship, in digital vigilantism participants assert "new boundaries" (Trottier, 2017, p. 59) in their relationship with authorised powers. Political, ideological, and other convictions of vigilantes can be shared by members of the state apparatus, and other functionaries holding legal power and authority. Some vigilante groups in Russia have even received presidential grants in support of their activities (Favarel-Garrigues, 2018; Gabdulhakov, 2018) in exchange for loyalty.

\subsection{Vigilantism in the Absence of Police}

When migrant communities find themselves in the situation where they are reluctant to turn to the formal police due to brittle immigration status in the host state, resorting to informal policing within own group is a way of maintaining unity and order. In his study on undocumented Mozambican migrants in Johannesburg, Madsen illustrates how internal migrant-over-migrant "policing produces the moral community and not the other way around" $(2004$, p. 174). As interaction with the formal police forces can lead to "harassment and deportation", migrants rely on each other in the phenomenon which Madsen describes as "neither policing in the traditional sense nor vigilante activity, but rather, a form of communally effected non-violent policing" (2004, p. 173). Migrants develop a dependency on each other for moral policing, where "social exclusion is a highly effective form of sanctions as survival depends on inclusion" (Madsen, 2004, pp. 188-189). Contrary to the case of Mozambican migrants in Johannesburg, actions of the so-called Kyrgyz 'patriots' largely fit the definition of digital vigilantism. Acts of retaliation are filmed and distributed online while shaming "serves as a moral justification in order to facilitate information sharing and socially harmful visibility" (Trottier, 2018, p. 171) where the subjective moral motivations of the 'patriots' lead to acts of community policing.

Vigilante acts can be centred around offences that imply the breaking of the law - "formal legal orders"; as well as offences based on the violation of subjective social norms-informal "not legally codified" orders "established and enforced by a range of non-state actors" (Moncada, 2017, p. 407). Applying this scheme to the selected case of Kyrgyz labour migrants in Russia stipulates that unlawful employment and violation of immigration regulations resemble the breaking of the formal orders in the host state. At the same time, migrants whose immigration status is in accord with the law still violate the informal orders in the perception of certain groups and individuals who view the very fact that foreigners live in Russia as offensive. In addition to this, the case illustrates that informal orders can be further violated within the target group, creating layers of vulnerabilities that subject targets to retaliation.

\subsection{Image as Power}

In their 2015 study on media discourses surrounding the case of Kyrgyz 'patriots', Ibraeva et al. conclude that "male migrants find themselves in a situation of identity destabilisation" amid the "loss of the normative role for a traditional society model of masculinity" (Ibraeva et al., 2015 , p. 24). Furthermore, the authors discover that respective discourses in the Russian and Kyrgyz media have "framed violence as patriotic, truly male and ethnic" and "became the backbone for new legitimation of violence" (Ibraeva et al., 2015, p. 25). These findings raise concerns over frames and discourses that surround such acts of crime. Traditional media reports not only justify violence but can also aid the offenders in amplifying the harms of undesired visibility by revealing the identity of targets in the reports. In cases where online content would other- 
wise not be available to some audiences, traditional media reports assist in disseminating the message.

In its turn, social media enables spectators to participate in digitally mediated retaliation. As a result, the audience is not just a passive observer; it plays an instrumental role in retaliation, intensifying and surpassing the impact of embodied assaults. Members of the audience can take sides and express their position on the issue through 'likes', 'dislikes', shares, and comments. Some vigilantes in Russia maintain an active and systematic approach to uploading videos on YouTube, with respective viewings counting in millions. Although select videos can get removed by platforms due to violent content, the nature of file storing and sharing on social media enables their continuous circulation. Besides, legal frameworks, approaches and capacities for removal of harmful content from platforms vary across contexts. While each wave of circulation of media material exposing the targets brings about new waves of harms, the longevity of online availability of these media implies the longevity of their damaging impacts on the targets.

In mediated retaliation, traditional media reports play a crucial role as their coverage of a given incident can boost online searches and hype a particular case. Furthermore, traditional media frame cases, participants, and targets in their reports. If the victims are unable to speak up (out of fear of further retaliation, shame, and due to other reasons), their voice is missing. As is argued by Jane (2017), in gendered cyberhate there is a "silencing effect" that leads to self-censorship of female targets (p. 191). Meanwhile, vigilantes who have an interest in instrumentalising their visibility enjoy the publicity. On top of this, participants' (in)formal collaboration with the police further limits targets in options for seeking legal help, as dysfunctionality of the legal system and structural advantages of vigilantes prevail.

\section{The Digital Divides...and Unites}

Scholars working on theorisation of the notion of digital divides (among others: Miller \& Norris, 2016; Ragnedda \& Ruiu, 2017; van Dijk, 2017) suggest a three-level distinction where the first level concerns physical and material access to electricity, the internet, and devices; the second level focuses on the character of use of digital media, respective skills and savviness of the users; while the third level of digital divides looks into different types of capital and benefits of using digital media. Within their definition of the digital divide, Miller and Norris (2016, p. 2) suggest that:

[S]ocial inequalities and power relationships that exist online at any given moment or in any given space shape, and are shaped by, access to and uses of ICT. To the extent that men and women are socialized differently and unequally, offline gender roles, responsibilities, and opportunities influence online behaviour and any corresponding benefits.
As such, at the third level, people's background and various types of acquired capital influence how they "reinvest valuable information in the social realm" (Ragnedda \& Ruiu, 2017, p. 25). Certain discourses and acts can create $a$ sense of unity for specific audiences in the us versus them representation of targets, i.e., men versus women, migrants versus locals, sexual minorities versus majorities, drivers versus pedestrians, merchants versus consumers, etc. These unifying sentiments are constructed over the condemnation of perceived norm breaching. The "imagined" online communities (Gruzd, Wellman, \& Takhteyev, 2011) inform and inspire offline discourses and acts. Among the many examples, this dynamic can be illustrated by a vigilante group based in Chechnya where participants find offence in how some Chechen women dress. Vigilantes take pictures of their targets and make use of the images that targets share on social media. They expose women to the digital audience, but also provide addresses of targets and call on offline actions, urging the relatives to take measures such as honour murder for the perceived misconduct (BBC, 2017). On their public platforms, participants warn the audience that only men can leave comments and that nonChechens will be banned from the discussion. Such categorisation creates a sense of unity among participants and the audience. Online perceptions of unity are intertwined with the offline contestations of norms and negotiation of us and them.

The discrepancy in the acquired benefits of social media use is evident in vulnerabilities and immunities of different users. The third level digital divide can be applied to mediated capacities of actors involved. Users with a social media following counted in millions, obviously have a greater audience outreach than those with just a few subscribers. Respective traditional media framing and official endorsement can turn vigilantes into informal public leaders. In this regard, such publicity and endorsement can grant vigilantes greater respect and support from the audience than the official state police could enjoy. Furthermore, traditional media and public discourses over viral cases of digital vigilantism can further inform collective perceptions and reactions to these events and practices, and in doing so, further inform social frustrations, biases, divides, and vulnerabilities.

In contexts where citizen involvement in justice matters is encouraged by the highest authority (in the case of Russia, by President Putin), the police are by default invited to collaborate with vigilante citizens (Gabdulhakov, 2018, p. 325). In this regard, the police can initiate formal collaboration with vigilantes by calling for public involvement in investigations and in the enforcement of legal orders through citizen-led surveillance, snitching, and denunciation of fellow citizens (The Moscow Times, 2018). Such practices, however, are not limited to formal orders and formal collaboration. The police and vigilantes can engage in informal solidarity and patron-client relations. Beyond this, police officers are also subjected to the power of visibility and can be respectively framed 
by vigilantes and/or by traditional media. As a Moscowbased leader of a vigilante group explained:

Sometimes I blackmail the police. For instance, I made a critical post on Facebook and exposed the investigator, and so on and so forth. At first, I received a phone call from the assistant of the Head of the press service and he asked me to remove the post. I said, "I will not remove anything, you deal with it yourself". To this, he said, "how can I help you?" I said, "put the paedophile in prison, and I will write positively about you...[i]f you take action, I will tell all media outlets how great you are". (Vigilante I)

This case exemplifies different media capacities of actors involved, which further complicates the relations between vigilantes, police officers, and targets.

\section{Migrants in the Bullseye of the Host State}

Central Asian republics of Kyrgyzstan, Tajikistan and Uzbekistan are large suppliers of labour migrants for Russia. This section of the article addresses vigilante acts where labour migrants are targeted by 'concerned' citizens in Russia. Described to be "the most violent country in the former Soviet Union for ethnic and racial minorities" (Arnold, 2015, p. 243), Russia presents a challenging environment for migrants as the perceived offence they emit is rooted in being foreign and non-Slavic. Vulnerable status induced by corruption, lawlessness, legal bureaucracy, legal illiteracy, language barriers, and fear of deportation, subjects Central Asians to abuse and retaliation performed both by the police (Alekseyeva, 2013; Kaliyev, 2018; Kislov \& Zhanaev, 2017; Sindelar, Bobomatov, Doorov, \& Kholov, 2013) and by the citizens in Russia (Kimmage, 2006; Parkin, 2018; SOVA Center for Information and Analysis, 2014; Yudina \& Alperovich, 2013, 2014). As one researcher from a Moscow-based NGO explained, "In the past, there was a negative perception of people from the North Caucasus republics, now the focus has shifted towards people from Central Asia...they are now perceived in sociological terms as 'the other'" (NGO I).

\subsection{Kyrgyz Labour Migrants in Russia: A Brief Profile}

Out of Kyrgyzstan's 6.2 million citizens (The World Bank, 2017), state migration service estimates 800 thousand people to be living abroad (Interfax, 2018). Precise information on the number of Kyrgyz labour migrants in Russia is not available. While Kyrgyz State Migration Service officials declare this number to be $640-650$ thousand (Interfax, 2018); Russia's Ministry of Interior is suggesting "more than 800,000" (Hasanova \& Kapushenko, 2018). Beyond this, Kyrgyzstan is leading globally in the share of remittances in the gross domestic product (GDP), with "nearly 40\%" of its GDP comprised of the money transferred by labour migrants (Hasanova \&
Kapushenko, 2018, para. 20). Worldwide Movement for Human Rights (FIDH) reports that in 2016 women constituted $40 \%$ of Kyrgyz labour migrants in Russia (2016, p. 4). In comparison, female migrants to Russia from other Central Asian republics, such as Tajikistan and Uzbekistan, represented less than $20 \%$ in each case (FIDH, 2016, p. 19). Based on the data available for 2014, estimated $60 \%$ of all Kyrgyz migrants did not possess proper documentation "to comply with current migration rules of countries of destination" (FIDH, 2016, p. 6). These data illustrate several important factors. Contrary to the case of other labour migrant-supplier states in the region, where men dominate the composition of this labour force, migrants from Kyrgyzstan are nearly equally balanced in the representation of men and women. While there is a domestic dependency on income from labour migration, lack of proper documentation during the stay in the host state creates a fertile ground for exploitation and abuse by the police, the employers, human traffickers, vigilantes, fellow migrants, etc.

\subsection{Migrant-Focused Vigilantes}

Among Russia's numerous citizen groups who have taken justice into own hands and retaliated on migrants and other minorities are the nationalists, football hooligans, pro-Kremlin youth groups, and neo-Nazi movements. Migrant-focused vigilante groups include Occupy Viselay [Occupy Evict], Mestnie [The Locals], Russkie [Russians], Movement Against Illegal Immigration, Scheet Moskvi [The Shield of Moscow], and numerous other formations that are in the constant flux of appearing and disappearing across the country. In most cases, social media is used by these groups to coordinate activities with the members and to spotlight these activities to the broader audience. Such visibility subjects the targets to greater retaliation and "further dehumanizes and relentlessly shames" them, while the punitive show is also used "to intimidate anyone who may have been watching and violating social rules" (Kasra, 2017, p. 185). Photo and video materials produced by such vigilantes not only harm the targeted individual, but serve as tools for mapping and targeting the larger 'other' - the alien group that these individuals represent, i.e., migrants, Central Asians, Muslims, nonSlavs, homosexuals, and other 'deviants'.

Having peaked in the mid-2000s, Russia's racist and neo-Nazi violence is experiencing a decline. As such, in 2008 Moscow-based SOVA Center reported that across Russia, "no less than 525 people were the victims of racist and xenophobic violence, 97 of whom died" (Kozhevnikova, 2009, para. 10). In 2010 "42 people died and 401 were injured" while in 2011 "23 people died and 154 received injuries" (Yudina, Alperovich, \& Verkhovsky, 2012, para. 11). Preliminary findings for 2018 report on 57 victims of "racist and other ideologically motivated violence" and "at least 4" deaths (Yudina, 2019, para. 6). The precise number of attacks on migrants is difficult to acquire as targets avoid the police, while 
the "attackers, who used to brag about their 'achievements' online, have grown more cautious in the wake of more active law enforcement pushback" observable in the last few years (Yudina, 2019, para. 7). Russia's vigilantes, thus, are manoeuvring between the benefits and the threats of visibility. Traditional media portrayal of events and actors further informs the audience. Framed as invaders and dangerous outsiders (Tolz, 2017), migrants have fewer chances for the compassion of the host state public in Russia. Respective legitimising framing of vigilantism, on the other hand, can inspire and attract supporters.

\subsection{Solidarity of Police and Vigilantes}

Until recent state-sanctioned crackdowns on the farright groups and movements in Russia (Lenta.ru, 2017, 2018; Petkova, 2017; Yudina, 2017), the police largely neglected cases of vigilante attacks on migrants and other minorities. Beyond this, a collaboration between vigilantes and the police was not an unusual arrangement. This collaboration concerned not only the proKremlin youth groups but extended to the nationalists who joined the so-called raids and "were also going sideby-side with the police and UFMS [Federal Migration Service]" (Rights defender I). While one of the interviewed law enforcement officers in Russia explained that rogue vigilantes more often get in the way of the police, rather than providing real assistance; collaboration, nevertheless, was viewed as a plausible option.

If they [vigilantes] want to help us, they should turn to us; we will find a job for them. Therefore, I, in fact, propose acting in accordance with the principle in which the Soviet druzhinas [volunteer militia] functioned. They did not determine the area of own work and own actions, but the police did so. The police determined where it needed assistance. This is exactly the key difference between the currently present movements and their help...although it is hard to even refer to this as help. There were druzhinas that were really of help for the police or the militia of that time. There is a huge difference between the two. (Police I)

Other interviewed law enforcement officers shared the sentiment of collaboration and stated that when it comes to law enforcement, "the police alone cannot manage, the society should be involved" (Police II).

Among the many disturbing acts performed by vigilantes targeting ethnic minorities in Russia were the socalled "white wagon" flash mobs, where the nationalists attacked "non-Slavic" people on a "train or subway car" (SOVA Center for Information and Analysis, 2014, para. 1). Sometimes in groups as small as five people, other times in mobs of 40-50 people wearing "knitted and medical masks" ultra-right groups committed hate crimes in public transport across Russia and while doing so, enjoyed "relative impunity" (SOVA Center for Information and Analysis, 2014, para. 10). Moscow-based rights defender further explains this police patronage over vigilantes as follows:

The main idea here is to have some fun, to beat someone up, and to have some coordinated relation in collaboration with the police. Without this link to the police, this activity would not be possible. No neighbourhood officer needs this amateur activity at all. This is only tolerated because there is some order for patronage from above. This is done to prevent mass fights. If they [nationalist vigilantes] are already going to be there anyway, it is better to take them under the patronage and to take their side as these are authorised activities, in a rather broad sense. (Rights defender I)

An academic specialising in Russia explains this relationship as a grey zone where state forces find some benefit in collaboration with vigilantes. "The state is not interested in completely eradicating this grey zone as there is always space for negotiation here. I don't think the state is very much interested in protecting gay rights or protecting migrant rights" (Academic I). Beyond media savviness, vigilante citizens are savvy about the methods they use in the context of Russia's legal system. When someone is murdered, a legal investigation has to be launched by default, but when someone is beaten and humiliated, the victim must first appeal to the police. "When the nationalists switched their methods and went from murder to beating and humiliating, it became even harder to keep them accountable, as no one files any complaints" (Rights defender II). Naturally, within the state-vigilante tandem and amid an array of other nuances and barriers, the process of seeking justice after subjection to retaliation is challenged. "If a person turns to the police, especially in a small town, they essentially bury themselves" a Moscow-based rights defender explained (Rights defender II). Furthermore, "turning to the police would cause recurrence of trauma, as victims would have to face their perpetrators again" (Rights defender III). Thus, even if the police were willing to take measures against vigilante forces, technically they would be lacking legal grounds to do so. A journalist from Kyrgyzstan who extensively researched and covered the life of Central Asian labour migrants in Russia explained the absence of legal appeals to the police as follows:

There are several reasons why the targets are silent. One of the reasons is that whenever there are illegal activities performed affecting the target, the target cannot necessarily turn to the police, because many migrants are undocumented or have an illegal registration. If such a person turns to the police for help, they would have to present an immigration card, but they cannot. They cannot present one, because their employers do not register them. There is a violation on top of a violation. (Journalist I) 
Even if the victim decides to turn to the police "in many cases the perpetrators are not arrested-and when some of them are, they are quite unlikely to be prosecuted for what their actions really consist in, that is, hate crimes" (SOVA Center for Information and Analysis, 2014, para. 10). These arrangements leave labour migrants with scanty options for seeking justice. Gender biases, patriarchal structures and traditional masculinity accompanied by social frustrations in the host state, subject female labour migrants to yet another stratum of violence.

\section{Female Migrants in the Bullseye of the Home State}

Female labour migrants are not only subjected to nationalism-based violence of host state vigilantes but also fall target to fellow compatriots. Weaponising the methods similar to those used against them by host state vigilantes, self-proclaimed 'patriots' target women for being "morally loose 'traitors' of the nation" because they establish relations with "men of other ethnicities (most often Tajiks)" (Ibraeva et al., 2015, p. 4). While the target is humiliated and exposed, vigilantes prefer to remain anonymous. One of the obvious reasons for anonymity is "the opportunity to avoid punishment", yet it apparently also serves a purpose of symbolising "a depersonified category of 'defenders of the fatherland, patriots'" (Ibraeva et al., 2015, p. 7). Expert interviews reveal that the 'patriots' are not a single or necessarily unified formation. Groups appear to be acting spontaneously across Russia. Much like in the case with antimigrant vigilantes, after experiencing retaliation, targets are limited in their options for seeking justice and face the same barriers and obstacles that prevent them from turning to the police, i.e., fear, lack of proper documentation, shame, the unreliability of the legal system, etc.

\subsection{Challenges in Being Vocal}

Journalists covering the case hold an important role in their interactions with the targets. Sometimes, during their interviews with the targets, the journalists persuaded them to be vocal and to turn to the police, with the hope that publicity of the case would scare the perpetrators and, as a result, would prevent future attacks. A journalist who worked closely with victims of the 'patriots' recalls: "One girl had written an appeal. I asked her to write it. She wrote an appeal to the police, to the local police [in Kyrgyzstan]. They started the case. They identified these men. But nothing happened. No one was brought to justice" (Journalist III). Sometimes the journalists covering the case are the only party the victim can rely on for assistance:

I found her [target of the 'patriots'] phone number and I called her, and I talked to her. Another girl, she came back to Kyrgyzstan and I found her with the help of the local police. They found her for me, as she was living with her parents. Her mother died and they [the police] helped me find her. I went there and interviewed her. She told me everything. We helped her. We took her to the crisis centre; we helped her out financially. (Journalist III)

At the same time, there are also concerns about the manner in which the journalists, the experts, and rights defenders respond to the issue. "What is interesting is that the experts and rights defenders, while having the desire to express their own stance on the matter, they share the videos. They, thus, contribute to the dissemination of these videos" (Journalist I). The stance on the issue of harms caused by traditional media reports is contested among the journalists themselves:

On the one hand, yes, you can view it as a perpetuation of retaliation. But, on the other hand, you also attract the attention of the society to a given issue. Many people were sharing [these videos] not because they support such acts, but because they were disturbed by them. (Journalist II)

Having failed to find justice, targets prefer to stay out of the media spotlight and are reluctant to continue cooperating with the journalists or other parties interested in the case. One of the interviewed journalists who had extensively written on targets of the 'patriots' attempted to write a follow-up story on a prominent case a few years after the initial coverage, but the victim refused to participate. "She does not want us to write about her, because she has children and they might read this material" (Journalist III). Additional harms erect when media coverage does not lead to the accountability of the perpetrators and instead intensifies the suffering of targets.

\subsection{No Support on the Home Front}

The society in the home state was polarised in its stance on the issue of digitally mediated honour beating of women by their male compatriots. One of the interviewed journalists provided the following account: "many were against the methods [of the 'patriots'], but some were in support. This may sound wild, but some people were supporting [the 'patriots'] and saying, 'yes, this is right, our girls should not be dating others'" (Journalist II). The appalling supportive moods are also evident in the survey conducted by the United Nations Population Fund [UNFPA], according to which:

[A] fairly large proportion of respondents (38\% of women and $45 \%$ of men) believe that women in migration, working away from home, begin to lead immoral life. On this basis, $51 \%$ of women and $55 \%$ of men support the activities of nationalist organizations, who "follow/or trace" the moral image of women from the Kyrgyz Republic, stripping, raping them and uploading their photos and "punishment" videos for bad behavior. $(2016$, p. 155) 
While condemning broader violence, state officials provide further legitimisation of the activities of the 'patriots' by scrutinising the victims. Kyrgyzstan's Interior Ministry representative in Moscow, for instance, made the following statement on Facebook after the punitive videos spread online:

The view of knives and stun guns should scare anybody who has seen these videos. But naturally, as a brother and future father, I cannot support the lifestyle that some of our young women lead, which provokes a strong reaction amongst Kyrgyz countrymen. (FIDH, 2016, p. 38)

The official also added that "when they [Kyrgyz women] come to Russia in search of work, they cannot resist all the challenges they encounter, and they become the playthings of Kyrgyz, Tajik, Uzbek and Caucasian men, who take advantage them" (Lelik, 2016). These perceptions, moods and discourses constitute social realities where female targets of digitally mediated abuse are further blamed offline.

Beyond this, back in the home state, nationalist movements engaging in moral policing with the focus on women, sexual minorities, and foreigners are also prevalent. An example of such forces is the so-called Kyrk Choro [Forty Knights] movement claiming membership of 5,000 across Kyrgyzstan (Lelik, 2015). Kyrk Choro carried out several nightclub raids in the country's capital of Bishkek where they have "lined up local women before a video camera" accusing them of prostitution (Lelik, 2015). Just like the Kyrgyz 'patriots' in Russia, Kyrk Choro members are concerned about Kyrgyz women dating foreigners and express anti-Chinese and anti-Uyghur sentiments (Chynybaeva \& Najibullah, 2015). These cases illustrate contested morality and nationalism in the host state of Kyrgyz migrants and raise important questions over the perceived roles and positions of women amid these contestations.

\section{Conclusion}

Digital media render important affordances in the lives of migrants, providing the ability to connect with friends and family, to store and access important documents, to connect with people in the host state, and numerous other possibilities. Yet, it is evident that offline inequalities, biases, and divides transmit into the digital sphere. Groups and individuals vulnerable offline are also vulnerable to online threats, such as digital vigilantism, where visibility is exploited as a magnifier of embodied harms. Through the selected case study of Kyrgyz labour migrants in Russia, this article illustrated how digital divides affect vulnerabilities across and within groups. Namely, the study presented a scenario where offline biases penetrate online and consequently re-inform the offline sphere. The study, in particular, demonstrated how within such a structure, women are subjected to multi- vector scrutiny, while their ability to be vocal and seek justice is challenged and jeopardised. Having crossed the Russian border, a female labour migrant from Kyrgyzstan is subjected to police abuse, retaliation by host state nationalist groups, and retaliation performed by male compatriots in migration. Falling victim to citizen-led retaliation in the host state, labour migrants are reluctant to turn to the police, as the police itself is an abusive force, which engages in patronage over vigilantes. As such, turning to the police can lead to abuse and deportation, while chances of bringing perpetrators to justice are minimal. Moreover, female labour migrants experience additional barriers to seeking justice in the home state due to social norms and biases that culminate in online and offline victim-blaming and shaming. Upon returning home, they are confronted by their relatives, by domestic nationalist groups, and by the greater community in the neighbourhood, village/town, and beyond. Digitally mediated retaliation, in its turn, brings about globality and permanence of exposure.

Further cross-national empirical research is necessary for a nuanced assessment of the digital divides and vulnerabilities in the context of social change, social benefits, and social harm that digital media renders. Specific contexts can include variant political environments as well as divergent social dynamics, positions, and norms. Studies could look beyond South-North migration and address cases in South-South and North-South migratory scenarios.

\section{Acknowledgments}

The author expresses sincere gratitude to the informants for their contributions. The author is grateful to the Media and Communication editorial office, and to peer reviewers for their invaluable feedback. Gratitude is expressed to Dr Amanda Paz Alencar and Dr Vasilki Tsagkroni for inspiring the author to contribute to this thematic issue. In addition, the author is grateful to Dr Daniel Trottier for his continuous support and guidance in the quest for the conceptualisation of digital vigilantism. This work is supported by the Netherlands Organisation for Scientific Research (NWO) grant "Digital Vigilantism: Mapping the terrain and assessing societal impacts", project number 276-45-004.

\section{Conflict of Interests}

The author declares no conflict of interests.

\section{References}

Alekseyeva, A. (2013). Russia's war on foreigners. First the Kremlin went after the gays. Now it's the "blacks". Foreign Policy. Retrieved from https://foreignpolicy. com/2013/09/05/russias-war-on-foreigners

Alencar, A. (2017). Refugee integration and social media: A local and experiential perspective. Informa- 
tion, Communication and Society, 21(11), 1588-1603. https://doi.org/10.1080/1369118X.2017.1340500

Alencar, A., Kondova, K., \& Ribbens, W. (2018). The smartphone as a lifeline: An exploration of refugees' use of mobile communication technologies during their flight. Media, Culture \& Society, 2018. https://doi. org/10.1177/0163443718813486

Arnold, R. (2015). Systematic racist violence in Russia between 'hate crime' and 'ethnic conflict'. Theoretical Criminology, 19(2), 239-256. https://doi.org/10. $1177 / 1362480615581102$

BBC. (2017). Zakrilsya chechenskiy pablic, oblichavshiy devushek v korotkikh yubkakh. [Chechen public revealing girls in short skirts has closed]. $B B C$. Retrieved from https://www.bbc.com/russian/news41246024

Beishinbek Kyzy, E., \& Bigg, C. (2012, May 31). Kyrgyz migrant women brutally assaulted in 'patriotic' videos. Radio Liberty. Retrieved from https://www.rferl.org/ a/kyrgyz-migrant-women-brutally-assaulted-inpatriotic-videos/24599390.html

Botoeva, G. (2012). Kyrgyz migrant workers: Does national pride mean violence against women? Open Democracy. Retrieved from https://www.open democracy.net/od-russia/gulzat-botoeva/kyrgyzmigrant-workers-does-national-pride-meanviolenceagainst-women

Chynybaeva, B., \& Najibullah, F. (2015). Kyrgyz group wrecks day against homophobia. Radio Liberty. Retrieved from https://www.rferl.org/a/kyrgyznationalists-wreck-day-against-homophobia/ 27023358.html

Favarel-Garrigues, G. (2018). Justiciers amateurs et croisades morales en Russie contemporaine [Vigilantism and moral crusades in contemporary Russia]. Revue française de science politique, 68(4), 651-667.

Foucault, M. (1977). Discipline and punish: The birth of the prison. New York, NY: Vintage.

Gabdulhakov, R. (2018). Citizen-led justice in postcommunist Russia: From comrades' courts to dotcomrade vigilantism. Surveillance \& Society, 16(3), 314-331. https://doi.org/10.24908/ss.v16i3.6952

Gruzd, A., Wellman, B., \& Takhteyev, Y. (2011). Imagining Twitter as an imagined community. The American Behavioral Scientist, 55(10), 1294-1319.

Hasanova, A., \& Kapushenko, A. (2018). Kyrgyzstan survives on money made by migrant workers, but it doesn't know how to spend it. Open Democracy. Retrieved from https://www.opendemocracy.net/ od-russia/kyrgyzstan-survives-on-money-made-bymigrant-workers-but-it-doesn-t-know-how-tospend-it

Ibraeva, G., Moldosheva, A., \& Ablezova, M. (2015). "We will kill you and we will be acquitted!": Critical discourse analysis of a media case of violence against female migrants from Kyrgyzstan. In T. Krussmann (Ed.), Gender in modern Central Asia. Zürich: LIT Verlag.
Interfax. (2018). Vlasti Kirgizii nazvali kolichestvo migrantov $v$ Rossii. [The authorities of Kyrgyzstan revealed the number of migrants in Russia]. Interfax. Retrieved from https://www.interfax.ru/russia/ 629250

Jane, E. (2017). Gendered cyberhate: A new digital divide? In M. Ragnedda \& G., W. (Eds.), Theorizing digital divides (pp. 186-198). Abingdon: Routledge.

Johnston, L. (1996). What is vigilantism? The British Journal of Criminology, 36(2), 220-236.

Kaliyev, A. (2018). Central Asian migrants describe injustice, racism in Russia. Caravanserai. Retrieved from http://central.asia-news.com/en_GB/articles/ cnmi_ca/features/2018/07/03/feature-01

Kasra, M. (2017). Vigilantism, public shaming, and social media hegemony: The role of digital-networked images in humiliation and sociopolitical control. The Communication Review, 20(3), 172-188. https://doi. org/10.1080/10714421.2017.1343068

Kimmage, D. (2006). Russia: Politics enters the mix in official response to murders. Radio Free Europe. Retrieved from https://www.rferl.org/a/1067894.html

Kislov, D., \& Zhanaev, E. (2017). Russia: Xenophobia and vulnerability of migrants from Central Asia. The Foreign Policy Centre. Retrieved from https://fpc. org.uk/russia-xenophobia-vulnerability-migrantscentral-asia

Kozhevnikova, G. (2009). Radical nationalism in Russia in 2008, and efforts to counteract it. In A. Verkhovsky (Ed), SOVA Center for Information and Analysis. Retrieved from https://www.sova-center.ru/en/ xenophobia/reports-analyses/2009/04/d15763

Lelik, A. (2015). Kyrgyzstan: Nationalist vice squad stirs controversy. Eurasianet. Retrieved from https://eurasianet.org/kyrgyzstan-nationalist-vicesquad-stirs-controversy

Lelik, A. (2016). Kyrgyzstan: Self-styled moral guardians operating with impunity. Eurasianet. Retrieved from https://eurasianet.org/kyrgyzstan-self-styledmoral-guardians-operating-with-impunity

Lenta.ru. (2017). Russkikh lyudei pritesnyayut. Pochemu v Rossii vser'yez vzyalis' za nesistemnikh natsionalistov. [Russian people are being harassed. Why in Russia they seriously went after the non-systemic nationalists]. Lenta.ru. Retrieved from https://lenta.ru/ articles/2017/07/24/ourboys

Lenta.ru. (2018). "Ya-Zhertva antisemitizma" Natsionalist Potkin o Gitlere, prorochestvakh Vangi i shutkakh nad evreyami. ["I am a victim of anti-Semitism" Nationalist Potkin talks about Hitler, the prophecies of Vanga and jokes about the Jews]. Lenta.ru. Retrieved from https://lenta.ru/articles/2018/04/19/potkin

Madsen, M. (2004). Living for home: Policing immorality among undocumented migrants in Johannesburg. African Studies, 63(2), 173-192.

Miller, B. P., \& Norris, C. M. (2016). Digital divide. In A. Wong, M. Wickramasinghe, R. hoogland, \& N. A. Naples (Eds.), The Wiley Blackwell Encyclopedia 
of gender and sexuality studies. https://doi.org/10. 1002/9781118663219.wbegss063

Moncada, E. (2017). Varieties of vigilantism: Conceptual discord, meaning and strategies. Global Crime, 18(4), 403-423. https://doi.org/10.1080/17440572. 2017.1374183

Parkin, S. (2018). The rise of Russia's neo-Nazi football hooligans. The Guardian. Retrieved from https://www.theguardian.com/news/2018/apr/24/ russia-neo-nazi-football-hooligans-world-cup

Petkova, M. (2017). The death of the Russian far right. How the Kremlin destroyed the far right in Russia, while backing it in the West. Al Jazeera. Retrieved from https://www.aljazeera.com/indepth/features/ 2017/11/death-russian-171123102640298.html

Ragnedda, M., \& Ruiu, M. (2017). Social capital and the three levels of digital divide. In M. Ragnedda \& G. W. Muschert (Eds.), Theorizing digital divides (pp. 21-34). Abingdon: Routledge.

Sindelar, D., Bobomatov, U., Doorov, T., \& Kholov, N. (2013). Central Asian migrants describe beatings, illtreatment in Russian market 'zachistki'. Radio Free Europe. Retrieved from https://www.rferl.org/a/russiaraids-migrant-labor-markets/25070219.html

SOVA Center for Information and Analysis. (2012). "Kyrgyz patriots" continue to mock their countrywomen for their connections to migrants from Tajikistan. SOVA Center for Information and Analysis. Retrieved from https://www.sova-center.ru/en/ xenophobia/news-releases/2012/05/d24483

SOVA Center for Information and Analysis. (2014). "White wagon" attacks. SOVA Center for Information and Analysis. Retrieved from https://www.sovacenter.ru/en/xenophobia/news-releases/2014/03/ d29226

The Moscow Times. (2018). Russian police to reward informants up to $\$ 150 \mathrm{~K}$ under new plan. The Moscow Times. Retrieved from https://themoscow times.com/news/russian-police-reward-informants150k-under-new-plan-62629

The World Bank. (2017). Kyrgyz Republic country profile. The World Bank. Retrieved from https://data. worldbank.org/country/kyrgyz-republic

Tolz, V. (2017). From a threatening "Muslim migrant" back to the conspiring "west:" Race, religion, and nationhood on Russian television during Putin's third presidency. Nationalities Papers, 45(5), 742-757. https://doi.org/10.1080/00905992.2017.1282449

Trottier, D. (2017). Digital vigilantism as weaponisation of visibility. Philosophy \& Technology, 30(1), 55-72. https://doi.org/10.1007/s13347-016-0216-4

Trottier, D. (2018). Coming to terms with shame: Exploring mediated visibility against transgressions. Surveillance \& Society, 16(2), 170-182. https://doi.org/10. 24908/ss.v16i2.6811

United Nations Population Fund. (2016). Gender in society perception study: National survey results. Bishkek: United Nations Population Fund. Retrieved from https://kyrgyzstan.unfpa.org/en/publications/ gender-society-perception-study

van Dijk, J. (2012). The network society (3rd ed.). London: Sage Publications.

van Dijk, J. (2017). Afterword. The state of digital divide theory. In M. Ragnedda \& G. W. Muschert (Eds.), Theorizing digital divides (pp. 199-206). Abingdon: Routledge.

Wall, M., Otis Campbell, M., \& Janbek, D. (2017). Syrian refugees and information precarity. New Media \& Society, 19(2), 240-254. https://doi.org/10.1177/ 1461444815591967

Worldwide Movement for Human Rights. (2016). Women and children from Kyrgyzstan affected by migration. World Movement for Human Rights. Retrieved from https://www.fidh.org/en/issues/ migrants-rights/central-asia-the-ordeal-of-migrantworkers-and-their-families

Yudina, N. (2017). Countering or imitation: The state against the promotion of hate and the political activity of nationalists in Russia in 2017. SOVA Center for Information and Analysis. Retrieved from https:// www.sova-center.ru/en/xenophobia/reportsanalyses/2018/03/d39029

Yudina, N. (2019). Far right and arithmetic: Hate crime in Russia and efforts to counteract it in 2018. SOVA Center for Information and Analysis. Retrieved from https://www.sova-center.ru/en/xenophobia/ reports-analyses/2019/02/d40603

Yudina, N., \& Alperovich, V. (2013). The State Duma directed right radicals toward new goals: Xenophobia, radical nationalism and efforts to counteract it in Russia during the first half of 2013. SOVA Center for Information and Analysis. Retrieved from https://www. sova-center.ru/en/xenophobia/reports-analyses/ 2013/08/d27659

Yudina, N., \& Alperovich, V. (2014). The ultra-right shrugged: Xenophobia and radical nationalism in Russia, and efforts to counteract them in 2013. SOVA Center for Information and Analysis. Retrieved from https://www.sova-center.ru/en/xenophobia/ reports-analyses/2014/03/d29236

Yudina, N., Alperovich, V., \& Verkhovsky, A. (2012). Between Manezhnaya and Bolotnaya: Xenophobia and radical nationalism in Russia, and efforts to counteract them in 2011. SOVA Center for Information and Analysis. Retrieved from https://www.sovacenter.ru/en/xenophobia/reports-analyses/2012/ 04/d24088 


\section{About the Author}

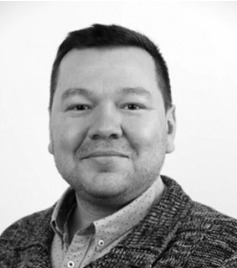

Rashid Gabdulhakov (MA, MASt) is a PhD Candidate at the Department of Media and Communication, at Erasmus University Rotterdam, The Netherlands. As a member of an international team of scholars, he is researching the phenomenon of digital vigilantism and its manifestation in Russia and other former Soviet republics. Rashid is teaching for the following courses: Academic Skills, International and Global Communication, Media Systems in Comparative Perspective, and New Media for Integration. For a full CV please visit https://www.eur.nl/en/eshcc/people/rashid-gabdulhakov 


\section{COGITATIO}

\section{Appendix}

\section{Interview data}

Academic I. Professor specialising in Runet (Russian internet). Skype interview in Moscow, Russia. April 2018.

Journalist I. Extensively covered Central Asian labour migrants in Russia. Interviewed in Bishkek, Kyrgyzstan. July 2018.

Journalist II. Extensively covered the case of Kyrgyz 'patriots'. Interviewed in Bishkek, Kyrgyzstan. July 2018.

Journalist III. Has access to the targets of the Kyrgyz 'patriots' and extensively covered the case. Interviewed in Bishkek, Kyrgyzstan. July 2018.

NGO I. Public opinion researcher in Russia. Interviewed in Moscow, Russia. May 2018.

Rights defender I. Specialises in cases of xenophobia. Interviewed in Moscow, Russia. May 2018.

Rights defender II. Specialises in legal aid for the victims of police abuse and vigilantes. Interviewed in Moscow, Russia. May 2018.

Rights defender III. Specialises in legal aid for the victims of police abuse and vigilantes. Interviewed in Moscow, Russia. May 2018.

Police I. Lieutenant colonel. Skype interview in Moscow, Russia. May 2018.

Police II. Moscow, Russia. Skype interview in Moscow, Russia. May 2018.

Vigilante citizen I. Paedophile buster. Interviewed in Moscow, Russia. May 2018. 